\title{
ELECTROCHEMICAL TREATMENT OF ELECTROPLATING WASTEWATER USING CARBON AND ALUMINUM ELECTRODES
}

Hewehy, M. A. I. $^{(1)}$; Abdel Razek, T. M. ${ }^{(1)}$; Hamid, M. M. A. ${ }^{(2)}$ and Morsy, Rehan, M. M.

1) Institute of Environmental Studies and Research, Ain Shames University,

2) Central Metallurgical Research and Development Institute (CMRDI)

\begin{abstract}
Heavy metal ions are frequently of high toxicity and require treatment to allowable standards for wastewater discharge. Electrochemical methods are more suitable for heavy metals removal because they can reduce metal concentration to the ppm range and allow recovery of valuable metal. The aim of this work is to treat electroplating wastewater using the electochemical corrosion of the sacrificial soluble alumnium electodes and insoluble carbon electrode using ferric chloride or alum as coagulant. Several working parameters, such as current intensity, electrode material, $\mathrm{pH}$ and time were tested. Results revealed that the best removal was achieved at 30 minutes and a potential difference 15 volt for aluminum electrode and10 volts for carbon electrode with ferric chloride. The removal efficiency percentage for synthetic solution of zinc, copper and nickel is $97.2 \%$, $97 \%$ and $96 \%$ respectively and for factory sample is $80 \%, 76.6 \%$ and $93.4 \%$ using aluminum electrode and for carbon electrode using ferric chloride to $97.5 \%, 97.2 \%$ and $97.1 \%$. and for factory sample is $81.6 \%$, $77.3 \%$ and $94.4 \%$.

The use of carbon electrode with $\mathrm{FeCl} 3$ is more suitable than aluminum electrode due to the dissolution of aluminum ions from electrode in the solution.
\end{abstract}

Keywords: Electrocoagulation, metal removal, potential difference, wastewater 
J. Environ. Sci.

Institute of Environmental Studies and Research - Ain Shams University

\section{INTRODUCTION}

All over the world one of the major challenges facing mankind today is how to provide clean water especially for the population in third world countries. Rivers, canals, and other water bodies are being constantly polluted due to indiscriminate discharge of industrial effluents in them. (Siringi, 2012). Various metals processing and finishing industries such as electroplating produce large volume of wastewater that contain many kinds of toxic substance such as acid, cyanide, alkaline cleaning agent, degreasing solvents, oil and grease and heavy metals. (Hansom, 2005).

These heavy metal bearing wastewaters must be treated before discharging because they are nonbiodegradable, highly toxic and probably carcinogen.

Only $30-40 \%$ of all metals in plating processes are effectively utilized in plated on the article and the rest consider as contaminantes which pollute the rinse water during plating process when the plated objects are rinsed upon removal from the plating bath (Lazaridis, 2005).

Electroplating rinse waters may contain up to $1000 \mathrm{mg} / \mathrm{l}$ toxic heavy metals which, according to the environmental regulations worldwide must be controlled to an acceptable level before being discharged to the environment (Dermentis, 2011).

The treatment of wastewater has become an absolute necessity. An effective and cheap method of purifying and cleaning wastewater before discharging into any other water systems is needed, many techniques for wastewater treatment are known which include biological processes (Bashaar, 2004) and physicochemical processes (Wang, 2004). One of the most promising techniques is based on 
electrochemical technology which being developed and improved to reduce chemical additions (Sarla, 2012).

Electrochemical recovery of metals is also most promising due to its high effectiveness, its lower maintenance cost, less need for labour and rapid achievement of results (Feng, 2003).

Electrocoagulation involves the generation of coagulant in situ by dissolving electrically either aluminium or iron ions from aluminium or iron electrodes respectively. Metal ions generation takes place at the anode, hydrogen gas would also help to float the flocculated particles out of the water. This process sometimes is called electroflocculation. The advantages of electrocoagulation include high particulate removal efficiency, compact treatment facility, relatively low cost and possibility of complete automation (Gao, 2008).

In electrocoagulation (EC) process the electrode can be arranged in a monopolar or bipolar mode. The materials can be aluminum or iron in plate form or packed form of scraps such as steel turnings, millings, etc.

The chemical reactions taking place at the anode are given as follows:

For aluminum anode:

$\mathrm{Al} \rightarrow \mathrm{Al}^{3+}+3 \mathrm{e}$

at alkaline conditions

$\mathrm{Al}^{3+}+3 \mathrm{OH}^{-} \rightarrow \mathrm{Al}(\mathrm{OH})_{3}$,

at acidic conditions

$\mathrm{Al}^{3+}+3 \mathrm{H}_{2} \mathrm{O} \rightarrow \mathrm{Al}(\mathrm{OH})_{3}+3 \mathrm{H}^{+}$.

The reaction at the cathode is

$2 \mathrm{H}_{2} \mathrm{O}+2 \mathrm{e} \rightarrow \mathrm{H}_{2}+2 \mathrm{OH}^{-}$.

(Chen, 2004). 
The chemistry behind the EC process in water is such that the positively charged ions are attracted to the negatively charged hydroxides ions producing ionic hydroxides with a strong tendency to attract suspended particles leading to coagulation (Ukiwel, 2014).

For carbon electrode: the most widely used metal coagulants are probably ferric chloride or aluminium sulfate. Ferric chloride and alum act as acids as they release hydrogen ions and lower the $\mathrm{pH}$ of the water.

$$
\begin{aligned}
& \mathrm{Fe}^{3+}+3 \mathrm{H}_{2} \mathrm{O} \rightarrow \mathrm{Fe}(\mathrm{OH})_{3}+3 \mathrm{H}^{+} \\
& \mathrm{Al}^{3+}+3 \mathrm{H}_{2} \mathrm{O} \rightarrow \mathrm{Al}(\mathrm{OH})_{3}+3 \mathrm{H}^{+}
\end{aligned}
$$

The alkalinity of ferric chloride and aluminum sulfate can be calculated using the stoichiometric reactions as follows:

$$
\begin{aligned}
& \mathrm{FeCl}_{3} \cdot 6 \mathrm{H}_{2} \mathrm{O}+3\left(\mathrm{HCO}_{3}{ }^{-}\right) \rightarrow \mathrm{Fe}(\mathrm{OH})_{3}+3 \mathrm{Cl}^{-}+6 \mathrm{H}_{2} \mathrm{O}+3 \mathrm{CO}_{2} \\
& \mathrm{Al}_{2}\left(\mathrm{SO}_{4}\right)_{3} \cdot 14 \mathrm{H}_{2} \mathrm{O}+6\left(\mathrm{HCO}_{3}{ }^{-}\right) \rightarrow 2 \mathrm{Al}(\mathrm{OH})_{3}+3 \mathrm{SO}_{4}{ }^{2-}+14 \mathrm{H}_{2} \mathrm{O}+6 \mathrm{CO}_{2}
\end{aligned}
$$

(Crittenden, 2005).

The aim of this work is to treat the electroplating wastwater and to determine the efficiency of electrocoagulation in removing metallic pollutants, such as zinc, copper and nickel from synthetic aqueous solutions and actual wastewater obtained from a local electroplating unit.

\section{MATERIAL AND METHODS}

The industrial highly acidic electroplating wastewater effluent was obtained from candilars plant which produce $30.000 \mathrm{~m}^{3}$ electroplating waste water per year, which includes variable amounts of heavy metals $(\mathrm{Cu}, \mathrm{Ni}$, $\mathrm{Zn})$. 
A synthetic electroplating wastewater solution was prepared from reagent grade chemicals without any fruther purification in 20 litter stock solution consists of $1 \mathrm{~g} / \mathrm{l}\left(\mathrm{NiCl}_{2}, \mathrm{CuSO}_{4}\right.$ and $\left.\mathrm{ZnCl}_{2}\right) \mathrm{pH}$ of the synthetic solution was adjusted by $\mathrm{H}_{2} \mathrm{SO}_{4}$ and $\mathrm{HCl}$ to $\mathrm{pH} 2$.

Experiments were carried out in a batch electrochemical cell (EC) of 500 $\mathrm{ml}$ capacity as shown in Fig 1 . The EC unit consists of a DC power supply and two electrodes of:Aluminum soluble electrodes and carbon insoluble electrode with dimensions of $(10 \mathrm{~cm} \times 3 \mathrm{~cm})$.

Both ferric chloride $\mathrm{FeCl}_{3}$ and alum $\left[\mathrm{Al}_{2}\left(\mathrm{SO}_{4}\right)_{3} \cdot 14.3 \mathrm{H}_{2} \mathrm{O}\right]$ was used with carbon electrode as primary coagulant

- The electrodes were cleaned by polishing, immersing in $10 \%$ hydrochloric acid and rinsing with tap water prior to every run then used in EC for the synthetic electroplating wastewater.

- The electroplating wastewater effluent concentration was maintained during each experiment.

- DC supply was used (25 volt and $100 \mathrm{amp}$ ) power supply

- The electroplating wastewater effluent $\mathrm{pH}$ was adjusted using calcium carbonate and sodium hydroxide to $\mathrm{pH} 9$. 

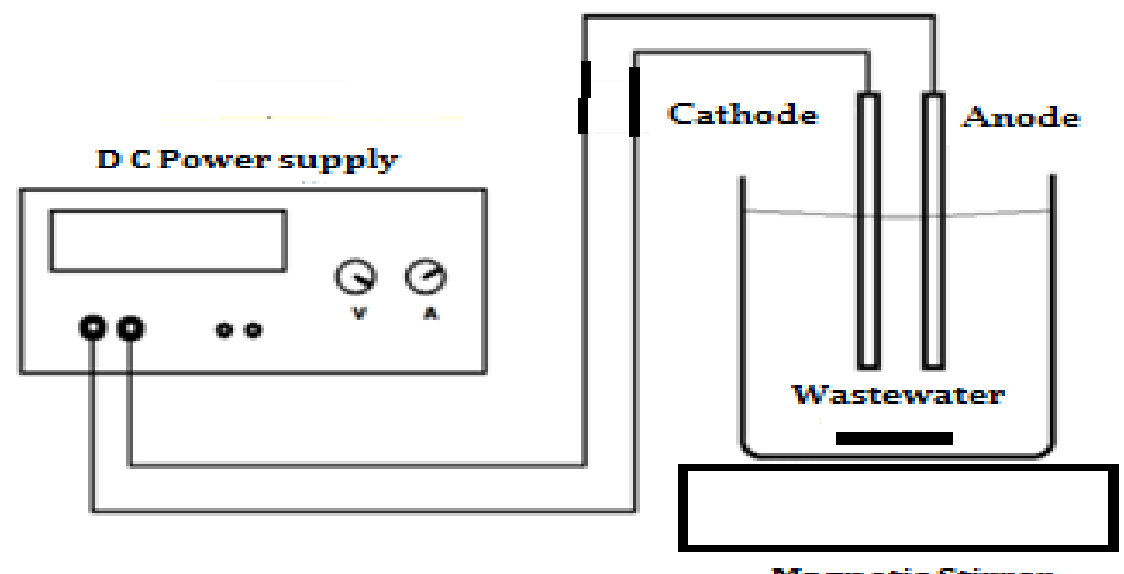

Magnetic Stirrer

Figure (1): Experimental setup of lab-scale electrocoagulation unit.

Before and after each run $1 \mathrm{ml}$ of polyacrylamide was added to the electrolytic solution for flocculation then the effluent was filtered and analyzed.

\section{For optimum Voltage:}

In order to evaluate the effect of voltage on the efficiency of removal of the heavy metals from the wastewater, a number of experiments were carried out at different voltage of 5,10,15 and $20 \mathrm{~V}$ at constant initial concentration of $1000 \mathrm{mg} / \mathrm{l}$ for $30 \mathrm{mins}$, and $\mathrm{pH}$ of 9 for zinc, nickel and copper with both aluminium electrode and carbon electrode with ferric chloride as coagulant.

\section{For optimum time:}

Then number of experiments were carred out at different time of 15, 30, 45, 60 min with optimum voltage with each electrode. 
After obtaining the optimum conditions for aluminum and carbon electrode with coagulant in electrocoagulation time and volt we applied them on the real effluent from the factory.

\section{Removal efficiency \% $=\underline{\mathrm{C}}_{\underline{0}} \underline{\underline{\mathrm{C}}} \underline{\underline{\mathrm{t}}} \times 100$ \\ $\mathbf{C}_{\mathbf{0}}$}

\section{RESULTS AND DISCUSSIONS}

\section{Effect of voltage on aluminum electrodes:}

Voltage is the product of the current delivered to the electrode and its resistance to flow. It determines the coagulant dosage rate, the bubble production rate and size and floc growth resulting in a faster removal rate (Ge, 2004). As the voltage increased, the efficiency removal also increased for all the metals. Fig (2) shows the highist removal efficiency of $97.2 \%, 97 \%$, and $96.8 \%$ was recorded for zinc, copper and nickel, respectively at 15 volts, This may be due to the formation of a passivating film on the aluminum anode at overpotential values higher than approximately $5 \mathrm{~V}$ and to the oxidation and reduction reactions which take place in the reactor. Also it may be attributed to the fact that at high voltage, the extent of anodic dissolution increased and the amount of hydro-cationic complexes resulted in increase of the removal efficiency, while they have decrease in heavy metal removal at 20 volts due to the presence of non reactive ions such as $\mathrm{Na}^{+}, \mathrm{SO}_{4}{ }^{2+}$ and $\mathrm{Cl}^{-}$ from the effluent that's cause a diffusion current which is equal but opposite to the migration current at steady state. (Chen, 2002). 


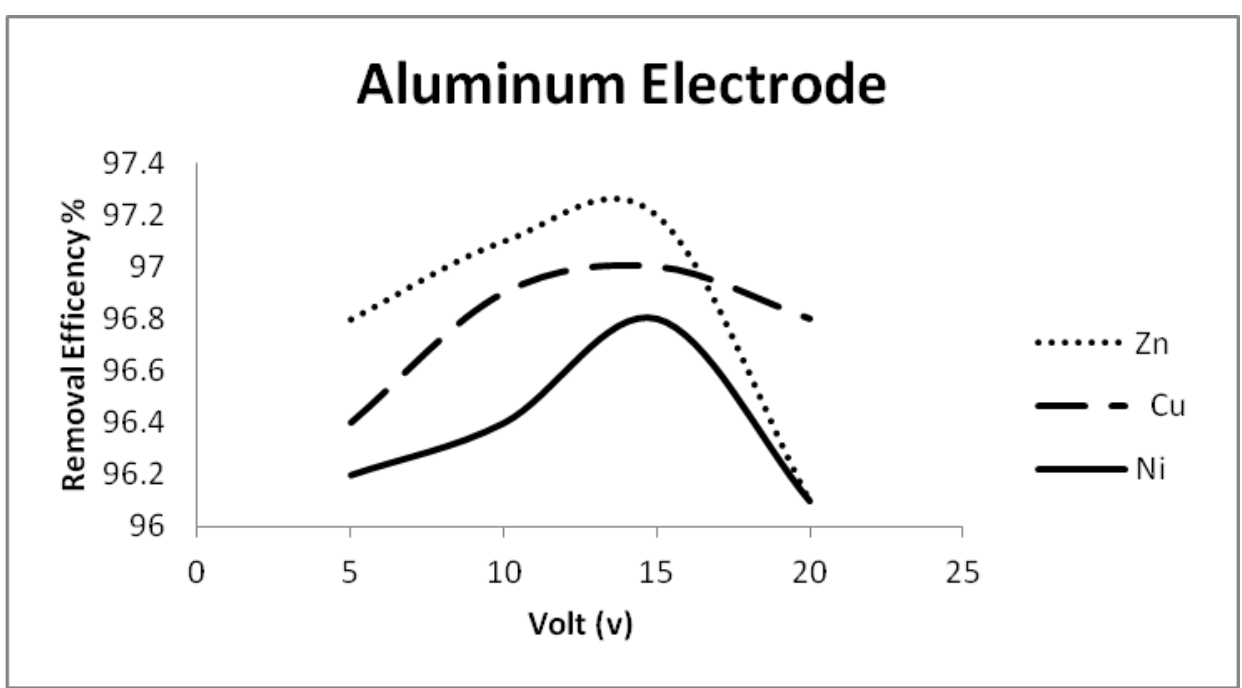

Figure(2): Effect of voltage on metal removal efficiency of , using aluminum electrode, concentration of zinc, copper and nickel $1 \mathrm{~g} / \mathrm{l} ; \mathrm{pH} 9$ and duration $30 \mathrm{~min}$.

It is well known that $\mathrm{pH}$ plays a significant role in electrocoagulation (Canizares, 2007). Some authors showed that, increases in $\mathrm{pH}$ lead to increase in the removal efficiency percentage. It was reported that the maximum removal \% of zinc, nickel and copper is at $\mathrm{pH}>8$ and (Tezcan and Ocal, 2015, Meena, 2010). It seems that at this $\mathrm{pH}$ precipitation of $\mathrm{Al}(\mathrm{OH})_{3}$ does not occur immediately in a substantial way (Lekhlif, 2014). It occurs only at the end of 30 minutes under 15 volt. Fig (3) showed that the Removal efficiency for aluminum ions resulted from aluminum electrode is 95.2 which is less than zinc, copper and nickel. At the same time, the concentration of $\mathrm{Al}^{3+}$ ions increased with the potential, and over time to stabilize at 15 volt . then the removal effiecincy $\%$ decreased with increasing the volt $>15$ due 
dissolution of aluminum ions and to the precipitation of the aluminum hydroxide.

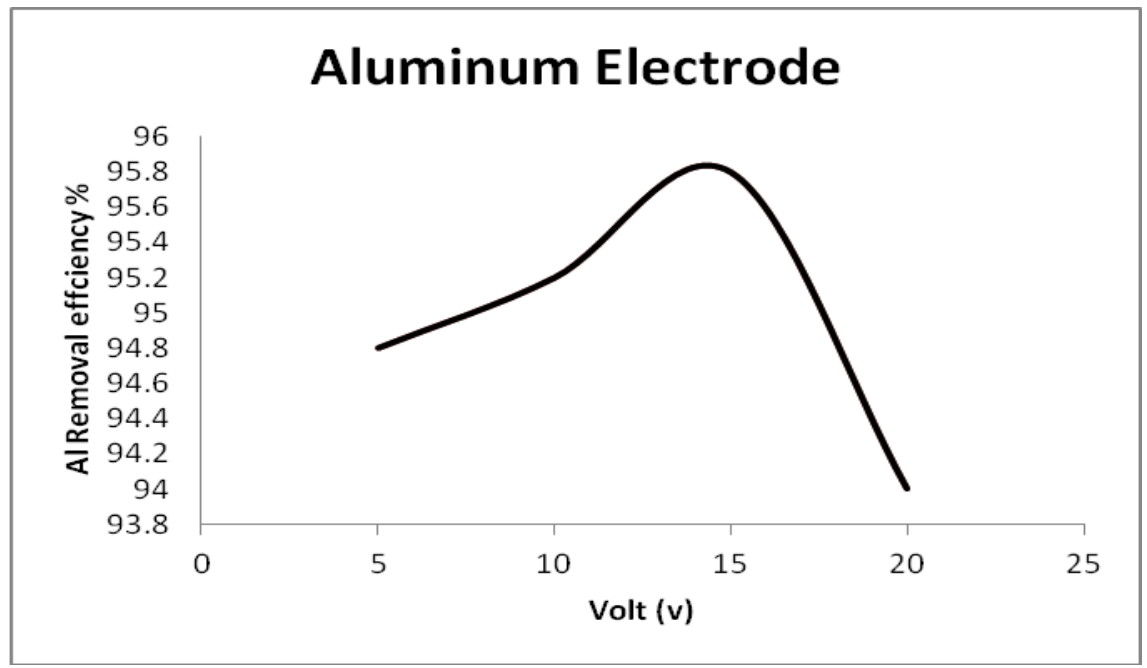

Figure (3): Effect of voltage on the removal efficiency of aluminum resulted from aluminum electrodes, $\mathrm{pH} \mathrm{9,} \mathrm{and} \mathrm{duration} 30 \mathrm{~min}$.

\section{Effect of voltage using carbon electrodes:}

Carbon, has been used as an electrode material in electrochemical applications for a long time and also used in metal removal. The electrodes produce reducing conditions and $\mathrm{H}_{2}$ at the cathode and oxidizing conditions and $\mathrm{O}_{2}$ at the anode. The electrodes provide the opportunity for sequential reduction and oxidation for metal removal ( Sun, 2012).

Ferric chloride $\mathrm{FeCl}_{3}$ and alum was used with carbon electrode as primary coagulants but the results of the intial experiments proved that ferric chloride give successful results with carbon electrode so it was fixed for the rest of experiments. 
From fig (4), it seems that increasing the applied potential, more $\mathrm{Fe}^{+3}$ and $\mathrm{OH}^{-}$were generated in the electrochemical cell which enhance the coagulant dosage which cause accelerated zinc, copper and nickel removal at a optimum value as $97.2 \%, 97.2 \%, 97.1 \%$ respectively at 10 volt and 30 minute. Above the critical value, dissolution of $\mathrm{Fe}^{+3}$ exceeded, leads to excessive generation of oxygen with consequent heat generation (Chaturvedi 2013). Therefore, no or more $\mathrm{Fe}^{+3}$ ions remain in the solution and decreased in zinc, copper and nickel removal to about $96 \%$, at $20 \mathrm{~V}$.

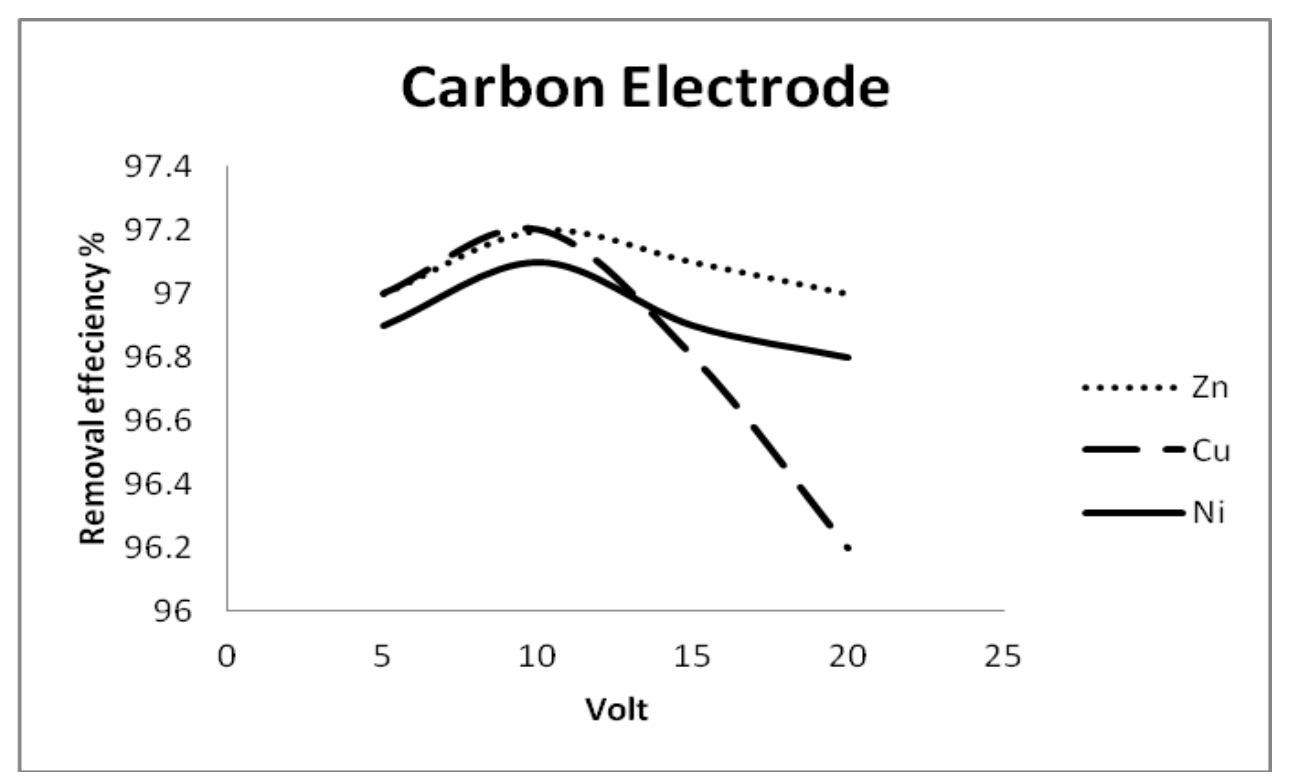

Figure (4): Effect of voltage on metal removal efficiency using carbon electrodes with $10 \mathrm{mg} / \mathrm{l} \mathrm{FeCl}_{3}$ as coagulant, concentration of zinc, copper and nickel 1g/l; pH 9 duration, $30 \mathrm{~min}$. 
Fig. (5) indicates that Effect of voltage on the removal efficiency of iron resulted from ferric chloride as coagulant increase with increasing volt, at pH9 and time 30 min are constant. Maximum removal efficiency percentage of iron ions achieved at 10 volt with $97.8 \%$ using carbon electrodes

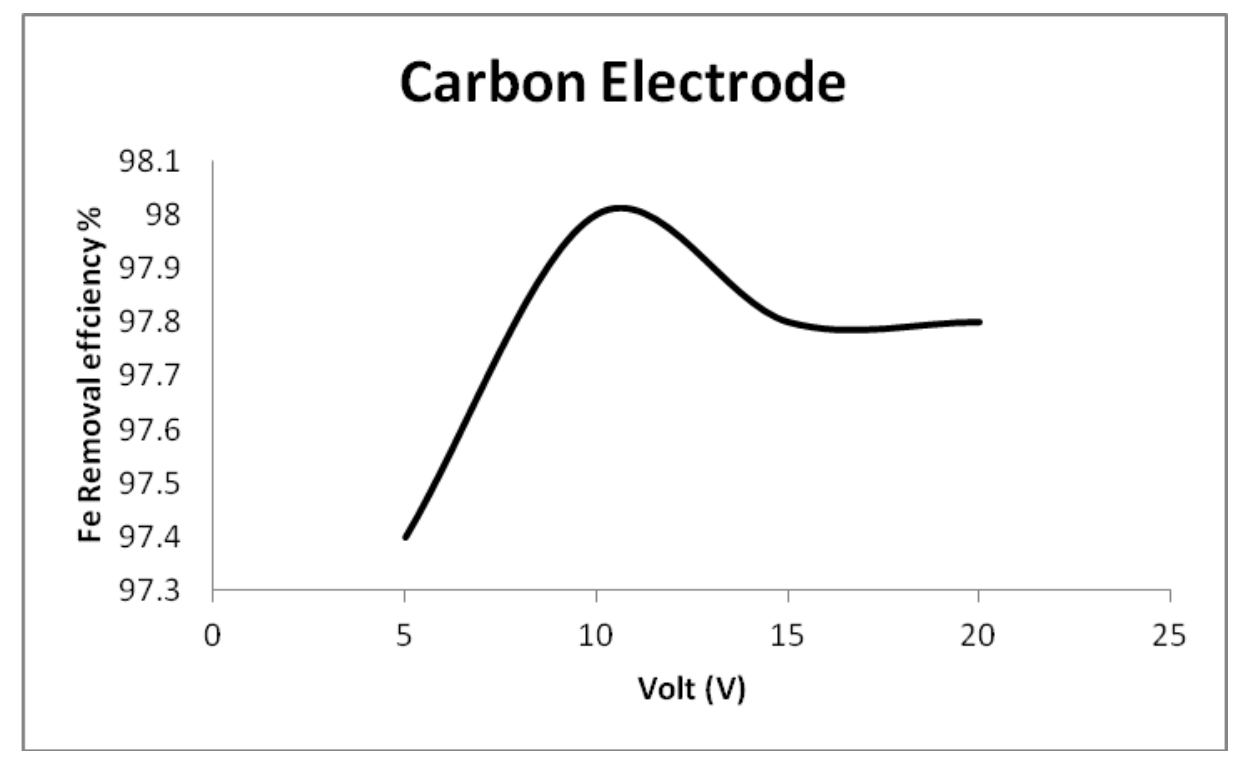

Figure (5): Effect of voltage on the removal efficiency of iron resulted from ferric chloride as coagulant using carbon electrodes, $\mathrm{pH} 9$ and 10 volt.

\section{Effect of Contact Time on carbon electrodes:}

Fig.(6) Shows the variation in the removal efficiency percentage of heavy metals with variation in contact time from 15-60 min using carbon electrode with intial concentration of zinc, copper and nickel $1 \mathrm{~g} / \mathrm{l}, \mathrm{pH}$ 9. It was observed that at a current voltage of 10 volt for carbon electrode with $\mathrm{FeCl}_{3}$ as coagulant, the maximum removal efficiency for zinc is $97.5 \%$, copper 
$97.1 \%$ and nickel is $97.2 \%$, respectively. By using aluminum electrode the dissolution of aluminum ions is more than iron ions resulted from using carbon electrode with $\mathrm{FeCl}_{3}$. The removal efficiency for aluminum is $95.2 \%$ and for carbon with $\mathrm{FeCl}_{3}$ is $97.8 \%$. The electrocoagulation efficiency for removing heavy metals from wastewater is high by using carbon electrodes with $\mathrm{FeCl}_{3}$ which is more suitable than aluminum electrode because there is no consumption of electrode mass and less consumption of ferric chloride as coagulant for the efficient removal of metal. Due to excess amount of floc. formation which ultimately sweeps away the metal from solution. Thus by electro-coagulation process, the discharge of the treated wastewater to the other water bodies or environment can be performed safety (Khosa, 2013).

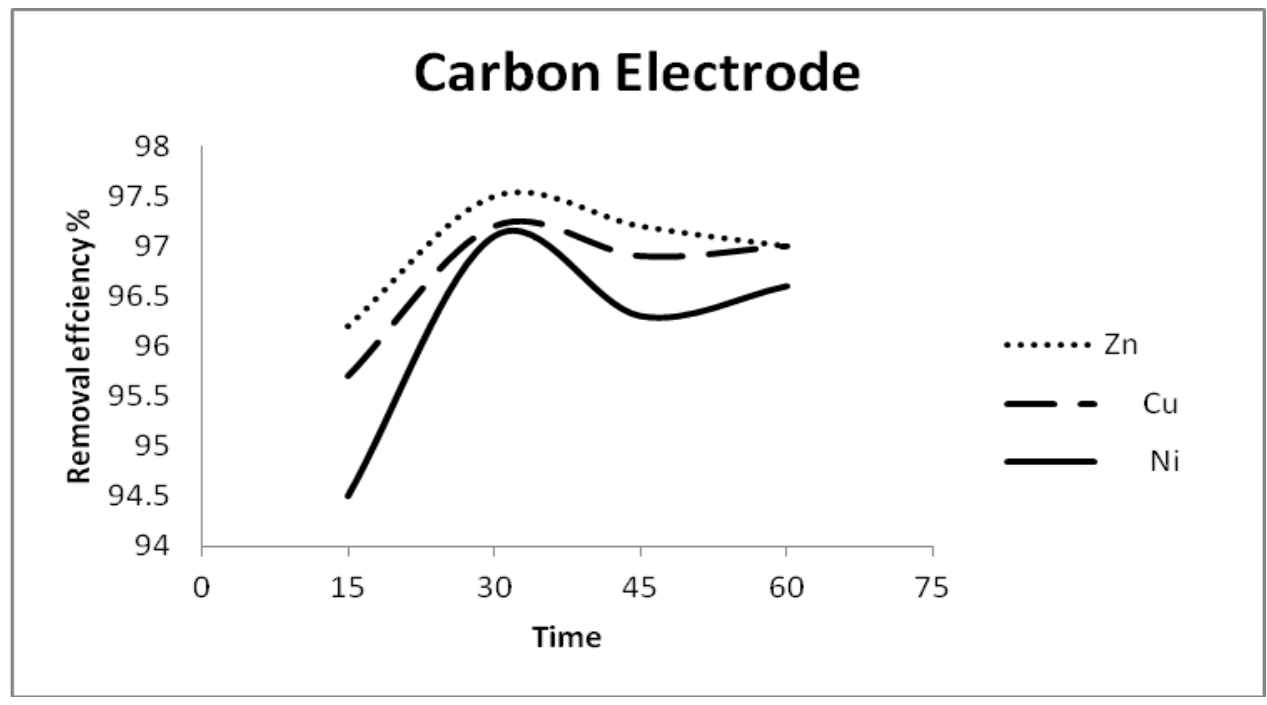

Figure(6): Effect of time on metal removal efficiency using carbon electrodes with $10 \mathrm{mg} / 1 \mathrm{FeCl}_{3}$ as coagulant, concentration of zinc, copper and nickel 1g/l; pH 9 and 10 volt 


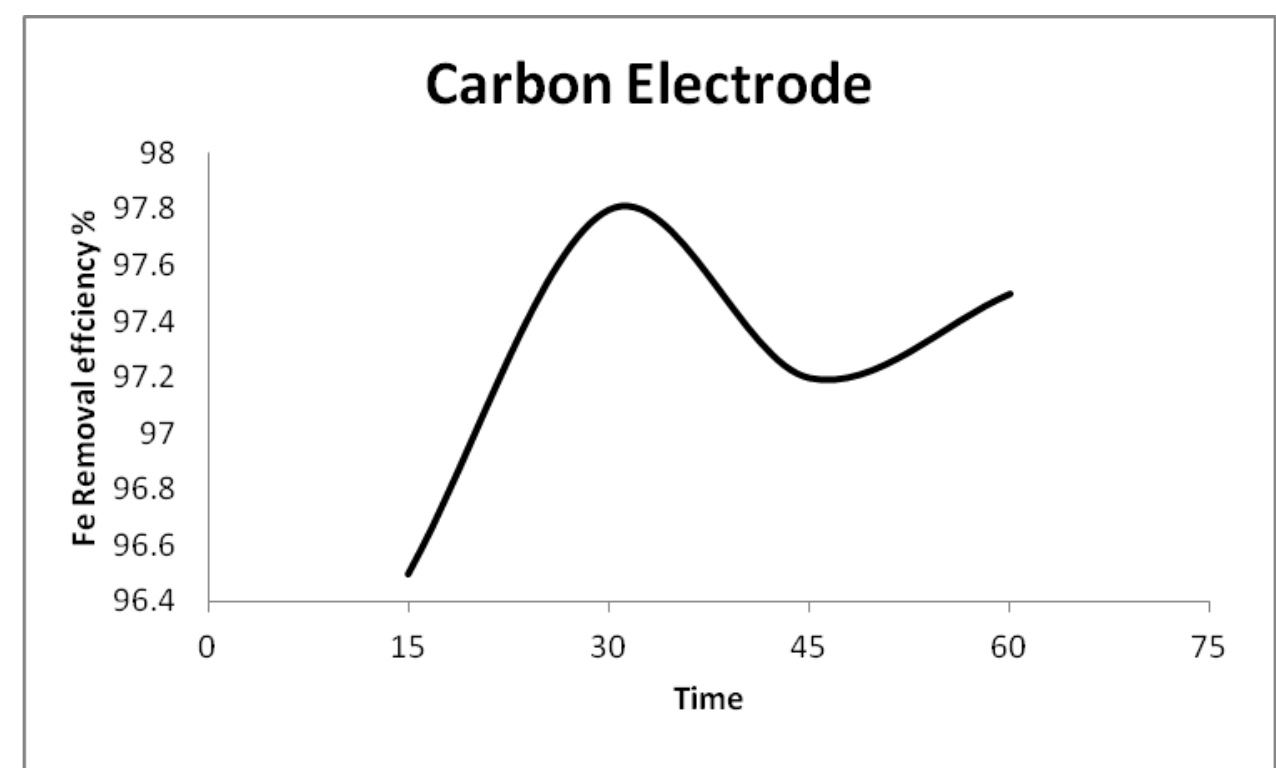

Figure (7): Effect of time on the removal efficiency of iron resulted from $\mathrm{FeCl}_{3}$ as coagulant using carbon electrodes, $\mathrm{pH} 9$, and 10 volts

\section{CONCLUSION}

The results of this study have shown the applicability of electrocoagulation in the treatment of electroplating wastewater containing copper, nickel and zinc. The most effective removal capacity was found that as the volt increased till $15 \mathrm{~V}$ in case of aluminum electrode and 10 in case of carbon electrode with $\mathrm{FeCl}_{3}$, the percent of the removal efficiency also increased then they decreased at 20volt. Also as contact time increased, the percent removal efficiency increased till $30 \mathrm{~min}$ by using aluminum and carbon electrodes with $\mathrm{FeCl}_{3}$ achieved at $\mathrm{pH}$ of 9 as the treatment efficiency was very poor either at low or high $\mathrm{pH}$. The experimental results showed that Carbon electrodes with $\mathrm{FeCl}_{3}$ are more efficient than Aluminum electrodes due to the presence of more aluminum ions in the solution. Also it may be 
because of high adsorption capacity of hydrous ferric oxides which gives highest removal efficiency values compared to aluminum optimized parameters as discussed above.

\section{REFERENCES}

Bashaar, A., (2004): "Nutrients requirements in biological industrial wastewater treatment", African Journal of Biotechnology, 3, (4), 236-238.

Canizares P.; Martinez F.; Lobato J.and Rodrigo A., (2007): "Breakup of oilin-water emulsions by electrochemical technique", Journal of Hazard. Materials, 145, (1-2), 233-240.

Chaturvedi, I., (2013): "Mercury Removal Using Fe -Fe Electrodes by Electrocoagulation" , International Journal of Modern Engineering Research, 3, (1), 101-108.

Chen, G., (2004): "Electrochemical technologies in wastewater treatment", Separation and Purification Technology" 38, 11-41.

Chen, X.; Chen, G. and Yue, P.L. (2002): " Investigation on the electrolysis voltage of electrocoagulation" Chemical Engineering Science $57,2449-2455$

Crittenden, C.; Trussel, R.; Hand, W.; Howe, J. and Tchobanoglous,G,(2005): MWH's water Treatment: Principles and Design "Second ed., John Wiley \& Sons, New Jersey, 643-779. .

Dermentis, K.; Christoforidis, A. and Valsamidou, E.(2011): "Removal of nickel, copper, zinc and chromium from synthetic and industrial wastewater by electro coagulation ", International Journal of Environmental Science, 5, (1), 697-710.

Feng, N.; Sugiura, S.; Shimada, T. and Maekawa, A., (2003): "Development of a high performance electrochemical wastewater treatment system", Journal of Hazardous Materials, 103, 65-78. 
Gao, Y.; Wang, Y.; Yue, Y.; Wei, C. and Li, Q. (2008): "The size and coagulation behavior of a novel composite inorganic- organic coagulant", Seperation and Purification Technolgies, 62, 544550 .

Ge, J.; Qu, J.; Lei, P.and Liu, H., (2004): "New bipolar electro- oagulation electroflotation process for the treatment of laundry wastewater. Seperation and Purification Technolgies, 36, 33-39.

Hansom, M.; Pruksathorn, K. and Damronglerd, S. (2005): "Electrochemical treatment of heavy metals $\left(\mathrm{Cu}^{2+}, \mathrm{Cr}^{6+}, \mathrm{Ni}^{2+}\right)$ from industrial effluent and modeling of copper" , Water Research, 39, (4), 610616.

Heidmann, K and Calmano, W., (2008): " Removal of Zn (II), Cu (II), Ni (II), $\mathrm{Ag}$ (II) and $\mathrm{Cr}$ (VI) present in aqueous solutions by aluminum electrocoagulation, Journal of Hazardous Materials 152, 934-941.

Janpoor, F; Torabian, A. and Khatibikamal, V., (2011): "Treatment of laundry waste-water by electrocoagulation"Journal of Chemical Technology and Biotechnology, 86, ( 8,), 1113-1120.

Joseph T.; Wabanne, N. and Anthony, C., (2013): "Treatment of Synthetic and battery industry wastewater by electrocoagulation", Der Chemica Sinica, 4,(6), 32-39.

Khosa, K.; Jamal, A.; Hussain, A.; Muneer, M.; Zia, M. and Hafeez, S., (2013): "Efficiency of Aluminum and Iron Electrodes for theRemoval of Heavy Metals [(Ni (II), $\mathrm{Pb}(\mathrm{II}), \mathrm{Cd}$ (II)] by Electro-coagulation Method", Journal of the Korean Chemical Society, 57, (3), 316-321.

Lazaridis, K.; Bakayannakis, N. and Deliyianni, A. (2005): "Chromium (VI) sorptive removal from aqueous solution by nano crystalline akaganeite, Chemosphere, (58), 65-73.

Lekhlif, B.; Oudrhiri, L.; Zidane, F.; Drogui, P.and Blais, J., (2014): "Study of the eletrocoagulation of electroplating industry wastewaters charged by nickel (II) and chromium (VI)", Journal of Material Environmental Science, 5, (1), 111-120. 
Meena, A.; Rajagopal, C. and Mishra, K., (2010): " Removal of heavy metal ions from aquas solutions using chemically $\left(\mathrm{Na}_{2} \mathrm{~S}\right)$ " Jornal of Industrial and Scientific Research, 69, 449-453.

Sarla, C. (2012): "Domestic wastewater water Treatment electrocoagulation with Fe-Fe Electrodes." , International Journal of Engineering Trends and Technology 3, (4), 530-533.

Siringi, O.; Patrick, H.; Chacha, J. and Kohen, E. (2012): "Electrocoagulation (EC) a solution to the treatment of wastewater and providing clean water for daily use," ARPN journal of engineering and applied science 7, (2), 197- 203

Sun,M.; Danny, R.; Lowry,V. and Gregory, B., (2012): "Effect of applied voltage, initial concentration and natural organic matter on sequential reduction/oxidation of nitrobenzene by graphite electrodes", Environmental Science Technolgies 46, (11), 617481.

Tezcan, U and Ocal, S., (2015): "Removal of Heavy Metals (Cd, Cu, Ni) by Electrocoagulation" International Journal of Environmental Science and Development, 6, (6), 425-429.

Ukiwel, N.; Jbeneme, I.; Duru, E.; Okolue, N.; Onyedika, O and Nweze, A. (2014): "Chemical and electrocoagulation techniques in coagulation-flocculation in water and wastewater treatment", A review AJRRAS, 18 , 285-294.

Wang, K. (2004): "Advanced physicochemical treatment process ", Hand book for environmental Engineering, Vol. 4, Totowa, New Jersey. 


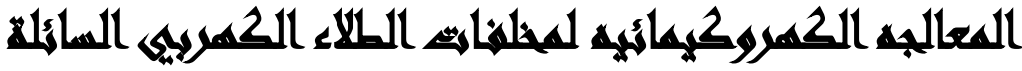

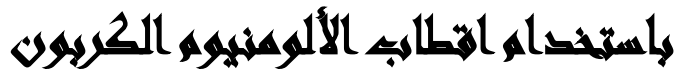

$[r]$

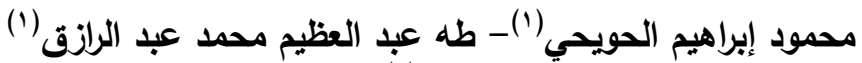

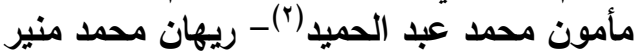

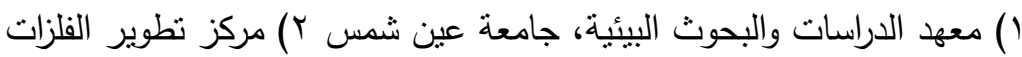

\section{المستخلص}

تعنبر ايونات الفلزات التقيلة من المواد عالية السمية والتي يجب ان يتم معالجتها والتخلص منها للوصول الى الحد المسموح به قبل صرفها في المصارف العاديه، وهناك طرق كثيرة لإزالة هذه الفلزات منها طريقة التخثر الكهربي والتي تعنبر من أهمها نظرا لكفاءتها في عملية الإزاله ولتقليل

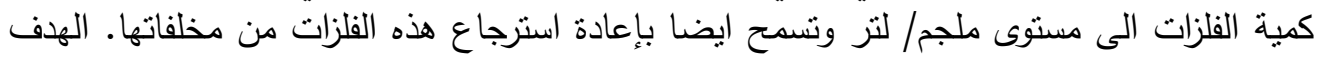

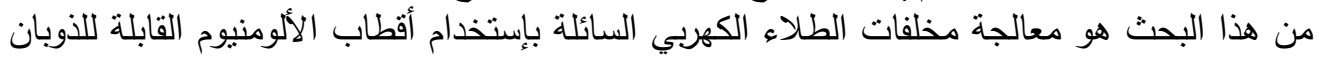
وأقطاب اخرى غير ذائبة منل الكربون مع مواد تخثز مثل كبريتات الألومنيوم و كلوريد الحديديك، وقد تم اختبار متغيرات متعدده منل فرق الجهذ، نوع الأقطاب المستخدمة، والزمن. ولقد اوضحت فون النتائج ان افضل إزالة تمت عند إستخدام فرق جهد 10 فولت في زمن مقدارة . ب دقيقة بإستخدام أقطاب

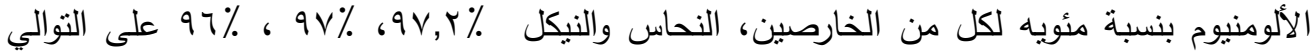

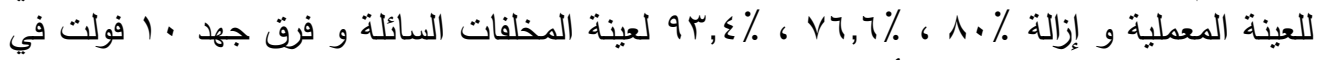
زمن مقدارة • r دقيقة بإستخدام أقطاب الكربون مع كلوربد الحديديك بنسبة مئويه لكل من الخارصين،

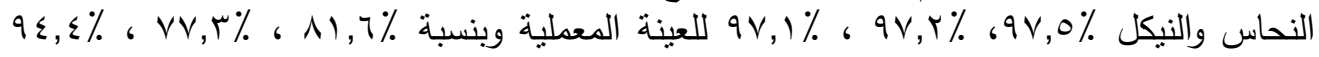
لعينة المخلفات السائلة. ولقد اوضحت النتائج ان استخدام أقطاب الكربون مع كلوربد الحديديك كمادة تخثر افضل في إزالة الفلزات من مخلفات الطلاء الكهربي السائلة من استخدام اقطاب الألومنيوم وذلك لإن قطب الألومنيوم (المصعد) يذوب بكمية كبيرة في المحلول مما بقلل كفاءته في عملية الإزلة. 